\title{
Ageing, exposure to pollution, and interactions between climate change and local seasons as oxidant conditions predicting incident hematologic malignancy at KINSHASA University clinics, Democratic Republic of CONGO (DRC)
}

\author{
Mireille Solange Nganga Nkanga', Benjamin Longo-Mbenza ${ }^{4 *}$, Oladele Vincent Adeniyi $i^{*}$,
} Jacques Bikaula Ngwidiwo ${ }^{1}$, Antoine Lufimbo Katawandja', Paul Roger Beia Kazadi ${ }^{2}$ and Alain Nganga Nzonzila ${ }^{3}$

\begin{abstract}
Background: The global burden of hematologic malignancy $(H M)$ is rapidly rising with aging, exposure to polluted environments, and global and local climate variability all being well-established conditions of oxidative stress. However, there is currently no information on the extent and predictors of HM at Kinshasa University Clinics (KUC), DR Congo (DRC). This study evaluated the impact of bio-clinical factors, exposure to polluted environments, and interactions between global climate changes (EL Nino and La Nina) and local climate (dry and rainy seasons) on the incidence of HM.

Methods: This hospital-based prospective cohort study was conducted at Kinshasa University Clinics in DR Congo. A total of 105 black African adult patients with anaemia between 2009 and 2016 were included. HM was confirmed by morphological typing according to the French-American-British (FAB) Classification System. Gender, age, exposure to traffic pollution and garages/stations, global climate variability (El Nino and La Nina), and local climate (dry and rainy seasons) were potential independent variables to predict incident HM using Cox regression analysis and Kaplan Meier curves.
\end{abstract}

Results: Out of the total 105 patients, 63 experienced incident HM, with an incidence rate of 60\%. After adjusting for gender, HIV/AIDS, and other bio-clinical factors, the most significant independent predictors of HM were age $\geq 55$ years $(H R=2.4 ; 95 \% \mathrm{Cl} 1.4-4.3 ; P=0.003)$, exposure to pollution and garages or stations ( $\mathrm{HR}=4.9 ; 95 \% \mathrm{Cl} 2-12$. $1 ; P<0.001)$, combined local dry season + La Nina ( $H R=4.6 ; 95 \% C l$ 1.8-11.8; $P<0.001)$, and combined local dry season + El Nino ( $H R=4 ; 95 \% \mathrm{Cl} 1.6-9.7 ; P=0.004)$. HM types included acute myeloid leukaemia ( $28.6 \% n=18)$, multiple myeloma $(22.2 \% n=14)$, myelodysplastic syndromes $(15.9 \% n=10)$, chronic myeloid leukaemia $(15.9 \% n=10)$, chronic lymphoid leukaemia $(9.5 \% n=6)$, and acute lymphoid leukaemia $(7.9 \% n=5)$. After adjusting for confounders using Cox regression analysis, age $\geq 55$ years, exposure to pollution, combined local dry season + La Nina and combined local dry season + El Nino were the most significant predictors of incident hematologic malignancy.

(Continued on next page)

\footnotetext{
*Correspondence: longombenza@gmail.com; vincoladele@gmail.com

${ }^{4}$ Faculty of Health Sciences, Walter Sisulu University, Private Bag X1, 5117

Mthatha, South Africa

${ }^{5}$ Cecilia Makiwane Hospital/Walter Sisulu University, Faculty of Health

Sciences, East London, South Africa

Full list of author information is available at the end of the article
} 
(Continued from previous page)

Conclusion: These findings highlight the importance of aging, pollution, the dry season, El Nino and La Nina as related to global warming as determinants of hematologic malignancies among African patients from Kinshasa, DR Congo. Cancer registries in DRC and other African countries will provide more robust database for future researches on haematological malignancies in the region.

Keywords: Environmental epidemiology, Hematologic malignancies, Aging, Central Africa

\section{Background}

Cancer constitutes a greater healthcare burden in developed countries than in less developed countries [1]. The occurrence of cancer is, however, increasing worldwide because of the growth and aging of the world population [1-6]. The increasing prevalence of established risk factors such as exposure to polluted environments, the interaction of global climate with local climate conditions, oxidative stress, rapid urbanization and economic transition are also contributory factors [3].

Hematologic malignancies (HM) are a leading cause of morbidity, co-morbidity, mortality, and disability in both rich and resource-poor countries such as Democratic Republic of Congo (DRC) [1, 5, 7-12]. The incidence of HM is associated with aging, exposure to pollution (in residence or in workplace) and endemic infections (HIV and other viruses) $[13,14]$. There is no comprehensive hypothesis regarding the manner in which these risk factors act.

DRC in general and its capital Kinshasa in particular are experiencing epidemiologic and nutritional transitions which are responsible for the increase in noncommunicable diseases (NCD) such as cardiovascular diseases, Type-2 diabetes mellitus (T2DM) and stroke. All of these are related to oxidative stress [15], aging and climate variability (El Nino-La Nina [16] and HM [8].

However, there has been no research at Kinshasa University Clinics (KUCs) or in DRC generally to improve our understanding of the roles of personal attributes, socioeconomic factors and physical environments in the emerging epidemic of $\mathrm{HM}$ in Kinshasa Province, a region experiencing many socio-economic and political crises. For this study, the researchers hypothesized that factors such as aging, pollution, hypoxic environment, climate change and cold seasons are all oxidant conditions increasing the vulnerability of patients to HM in KUCs.

Therefore, this study evaluated the impact of bioclinical factors, exposure to pollutants and interactions between global climate change (El Nino-La Nina) and local seasons on HM incidence.

\section{Methods}

\section{Study design}

This study was a KUC-based prospective study involving 105 black African adult patients with anaemia between 2009 and 2016.

\section{Sampling}

The study population comprised anaemic black African patients according to pre-defined inclusion and exclusion criteria. This eligible population was characterized by chronic anaemia with episodic fever and fatigue.

\section{Sample size}

$$
N=4\left(\mathrm{Z}_{\alpha}\right)^{2} \mathrm{P}(1-\mathrm{P}) / \mathrm{W}^{2}
$$

Where $\mathrm{N}$ is the sample size, $\mathrm{Z}_{\alpha}$ the $\mathrm{Z}$-value for a two sided $\alpha$ of 0.05 and therefore a confidence interval of $95 \%, \mathrm{P}$ is the proportion of people with chronic anaemia expected to present with incident HM. Since the proportion of people with chronic anaemia who present with incident HM in the study population was not known, the authors assumed a proportion of 0.5 which will give the maximum sample size estimate [17], and a width or acceptable error (W) of 0.2 (i.e. an incidence of $0.5 \pm 0.2$ ). For a two sided $\alpha$ of 0.05 and therefore a confidence interval of $95 \%, z_{\alpha}=1.96$.

So the sample size $N=4(1.96)^{2}(0.5 \times 0.5) / 0.04$.

$N=96$ which was approximated to 100 .

Allowance for missing data was made: $100+20 \%$ of potential misses $=120$.

Inclusion criteria were age $\geq 20$ years and myelogramdiagnosed HM. Patients with any myelogram result other than HM and those patients who did not wish to participate in the study were excluded.

\section{Laboratory data}

To define structural (morphological) markers for diagnosing HM, $3.5 \mathrm{ml}$ of blood were obtained by venepuncture in tubes with anticoagulant ethylenediaminetetraacetic acid (EDTA) for the hemogram. In addition, three smears of peripheral blood were performed. A sample taken from a tube with $3.8 \%$ citrate was used for the determination of the erythrocyte sedimentation rate (ESR). The bone marrow aspiration was performed either at the level of the breastbone or at the level of the posterior iliac spine to collect $0.5 \mathrm{ml}$ of medullary content. Ten slides were displayed for the morphological study using the May Grünwald Giemsa (MGG) stains and for the special stains (Sudan black B, Periodic Acid Shift, Coloring of Perls). Medullary smears were also obtained for colored staining 
using the MGG viewed under the multi-ordinary microscope typical of Olympus.

\section{Potential predictors}

Independent variables were age, sex, infectious syndrome (HIV/AIDS, sepsis, and bacteremia), blood transfusion count, levels of hematologic markers (hemoglobin, white cell count and platelets), exposure to pollution, global climate variability (El Nino-La Nina), and local climate (seasons).

Information on gender, age, exposure to traffic pollution and garages or stations, global climate variability (El Nino and La Nina), and local climate (dry and rainy seasons) was obtained. Climate changes caused by global warming conditions caused climate variability, which was defined as short-term fluctuations around the mean climate state. Climate variability also refers to changes in climate patterns such as precipitation, weather conditions, temperature and humidity [16]. El Nino Southern Oscillation is associated with climate changes in the tropical and sub-tropical regions as a result of temperature anomalies from the warming and cooling of the ocean surface $[18,19]$.

El Nino can be defined as warmer-than-normal sea or ocean surface temperatures [16] and La Nina refers to cooler-than-normal sea or ocean surface temperatures [16]. El Nino years (2009, 2010, 2013 and 2015) and La Nina years (2011, 2012 and 2014) were defined by the THI Oceanic Nino Index (ONI). (http:// www.cpc.ncep.noaa.gov/products/analysis_monitoring/ ensostuff/ensoyears.shtml).

Local climates and seasons were defined by meteorological parameters (monthly temperatures, humidity, winds, fog, and precipitation). The dry season (very dry for June to September and less dry for January to March), cold months and rainy periods (high rainfall for October to December, lower rainfall for April and May) characterized the local climate. The interaction between global climate variability and local climate typically followed the pattern of: local dry season + global La Nina; local dry season + global El Nino; local rainy season + global La Nina; and local rainy season + global El Nino.

Places of residence and/or occupation close to hightraffic-volume roads, stations/garages, sources of dust, smoke or industrial pollutants were classified as polluted environments.

The clinical variables were infectious syndromes (bacteraemia, sepsis), bone pain, fever, splenomegaly and fatigue.

\section{Dependent variable}

The incidence of HM and each of its subtypes was confirmed by morphological typing according to the French-American-British (FAB) WHO classification system (Mounia, WHO).

\section{Statistical analysis}

The reliability and validity of this research relies on the accuracy of data and the consistency of the tools and procedures used-the research design. In order to achieve the highest standard of accuracy, the researchers avoided confounding factors and foreseeable information bias and selection bias.

In a univariate analysis, continuous variables were symmetrical and expressed as means \pm standard deviation (SD), compared between two groups (HM and patients with anaemia but having a normal myelogram) using the Student's t-test. However, categorical variables were presented as frequencies $(\mathrm{n}=$ number $)$ and prevalence (\%), comparing the two groups using the chisquare test. The researchers performed logistic regression and the Cox regression model to calculate adjusted multivariate hazard ratios ( $\mathrm{HR}=$ beta exponential) for the risk of incident HM with their corresponding 95\% confidence interval (95\% CI). Kaplan-Meir curves after the Cox regression model produced a one minus cumulative survival function with a log-rank test of the equality of survival distribution and time medians for the different levels of stratified covariates.

As age and laboratory optimal cut-off points were unknown, the effective (accurate and sensitive) cut-off values for discriminating $\mathrm{HM}$ and normal myelogram were tested a posteriori, using the Receiver Operating Characteristic curves (ROC) method. The area under the curve (AUC for c-static) was calculated with its corresponding Standard Error (SE), 95\% CI, and $P$-value. The criterion for two-sided statistical significance was $p$ value $<0.05$. All analyses were performed using SPSS software version 23.0 for Windows (IBM/SPSS Inc., New York, USA).

\section{Results}

Of the total number of patients $(n=105), 53.3 \%$ $(n=56)$ were males and $46.7 \%(n=49)$ were females, giving a sex ratio of almost 1:1. The incidence of HM in all patients was $60 \%(n=63)$; with a slightly higher incidence in males than in females $(55.6 \%, n=35$ for men vs. $44.4 \%, n=28$ for women). In the normal myelogram group, the figures were $50 \% n=21$ for men vs. $50 \%$ $n=21$ for women), without any significant impact of sex $(P=0.576)$ on HM incidence.

In considering incidences $(P=0.161)$ across HM subtypes, the sex ratios of men to women were different, as follows: in myelodysplastic syndrome (MDS), the sex ratio of men to women was 4:1 (8 men vs. 2 women). In multiple myeloma (MM), the sex ratio of men to women was 3:1 (10 men vs. 4 women). In acute myeloid leukaemia (AML), the sex ratio of men to women was 1: 1 (10 man vs. 8 women). In chronic myeloid leukaemia (CML), the sex ratio of men to women was 1:1 (4 men 
vs. 6 women). In acute lymphoid leukaemia (ALL), the sex ratio of men to women was 1:1 (2 men vs. 3 women) and in normal myelogram results the sex ratio was 1:1 (21 men vs. 21 women).

In chronic lymphoid leukaemia (CLL), the sex ratio was paradoxically 5 women: 1 man (5 women vs. 1 man). In the participants with incident HM, higher age, blood transfusion count and white cell count, but lower levels of haemoglobin and platelet counts, were observed as significant $(P<0.005)$, more than in patients with normal myelogram results (Table 1). In incident HM patients, Table 2 shows significant associations between aging (yes $\geq 50$ years), HIV/AIDS (yes), bacteraemia (yes) and incident $\mathrm{HM}$.

The prevalence of HIV/AIDS varied significantly $(P<0.0001)$ across HM subtypes, as follows: The highest rate was in MM $(n=8 / 14)$, intermediate rates were in $2 / 5$ of ALL, and rates of 2/6 were found in CML. The lowest rates of HIV/AIDS were 3/18 for AML, 1/10 for MDS and 2/42 for normal myelogram. The trends of incident HM peaked in El Nino 2009 and the lowest incidence was seen in La Nina 2014. The peak incidence of HM was observed between June to August, the very dry season. The majority of patients with HM were diagnosed during the dry and cold season. However, there was no significant difference in HM incidence by global climate variability.

In univariate analysis, the local dry and cold season, both the La Nina/cold season and El Nino/warm season, combined local dry season + global La Nina, and exposure to pollution were significantly associated with HM incidence (Table 3).

Among all markers of $\mathrm{HM}$, only the mean values of platelets varied significantly across combined global and local climates. The lowest levels of HM were observed in the local dry season + global La Nina and the highest levels were observed in the local rainy season + global El Nino.

After adjusting for mean values of platelets, sepsis, HIV/ AIDS, and bacteraemia, using Cox's regression analysis, the significant independent predictors of incident HM

Table 1 Comparison of mean values of age, blood transfusion, and hematologic parameters between HM incident $(n=63)$ and normal myelogram $(n=42)$

\begin{tabular}{llll}
\hline Variables & $\begin{array}{l}\text { HM incidence } \\
\text { Mean } \pm \text { SD }\end{array}$ & $\begin{array}{l}\text { Normal } \\
\text { myelogram } \\
\text { Mean } \pm \text { SD }\end{array}$ & p-value \\
\hline Age (years) & $61 \pm 16.5$ & $39.5 \pm 13.8$ & $<0.0001$ \\
$\begin{array}{l}\text { Blood transfusion } \\
\text { (number) }\end{array}$ & $9.6 \pm 3.6$ & $2.2 \pm 1.1$ & $<0.0001$ \\
Hemoglobin (g/dL) & $6.8 \pm 2.5$ & $8.2 \pm 2.6$ & 0.005 \\
White cell count $\left(\mathrm{mm}^{3}\right)$ & $22,936 \pm 22,244$ & $7029 \pm 4053$ & $<0.0001$ \\
Platelet (mm ${ }^{3}$ ) & $189,395 \pm 118,948$ & $249,107 \pm 151,751$ & 0.026 \\
\hline
\end{tabular}

SD standard deviation
Table 2 Univariate association between aging, sepsis, HIV/AIDS, bacteraemia, and HM Incidence

\begin{tabular}{lll}
\hline Variables & $\begin{array}{l}\text { HM incidence } \\
\%(\mathrm{n})\end{array}$ & $p$-value \\
\hline Age & & \\
Yes $\geq 50$ years & & \\
No $<50$ years & $34.8(16 / 4 / 59)$ & \\
Sepsis & & $<0.0001$ \\
Yes & $37.9(11 / 29)$ & \\
No & $68.4(52 / 76)$ & \\
HIV/AIDS & & 0.0002 \\
Yes & $28.6(18 / 63)$ & \\
No & $4.8(2 / 42)$ & $<0.0001$ \\
Bacteremia & & \\
Yes & $75(45 / 60)$ & \\
No & $40(18 / 45)$ &
\end{tabular}

HM haematological malignancy

were: exposure to pollution, with a six-fold risk increase; combined local dry season + global La Nina, with a threefold risk increase; combined local rainy season + global El Nino, with a three-fold risk increase; combined local dry season + global La Nina, with a two-fold risk increase; and aging with a two-fold risk increase (Table 4).

\section{Discussion}

This is the first time the factors of aging, sex, infectious syndrome, traditional hematologic markers, exposure to pollution (residence or occupation close to traffic, stations/garages, dust, smoke, or industrial areas), local

Table 3 Univariate association between local climate, global climate, combined global and local climate, exposure to pollution, and $\mathrm{HM}$ incidence

\begin{tabular}{lll}
\hline Variables & HM incidence & $p$-value \\
\hline Local climate & & \\
Dry cold season & $83.9(52 / 62)$ & $<0.0001$ \\
Rainy and hot season & $25.6(11 / 43)$ & \\
Global climate variability & & \\
La Nina and cold & $72.1(31 / 43)$ & 0.035 \\
El Nino and warm & $51.6(32 / 62)$ & 0.035 \\
Combined global and local climate & & \\
Local dry season + global La Nina & $86.7(26 / 30)$ & $<0.0001$ \\
Local dry season + global El Nino & $81.2(26 / 32)$ & \\
Local rainy season + global La Nina & $32.5(5 / 13)$ & \\
Local rainy season + global El Nino & $20(6 / 30)$ & \\
Exposure to pollution & & $<0.0001$ \\
Yes & $83.8(57 / 60)$ & \\
No & $16.2(6 / 37)$ & \\
\hline
\end{tabular}


Table 4 Independent predictors of HM incidence using multivariate Cox's Regression analysis

\begin{tabular}{|c|c|c|c|c|c|c|c|c|}
\hline \multirow{2}{*}{ 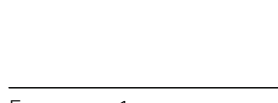 } & \multirow[t]{2}{*}{ B } & \multirow[t]{2}{*}{ SE } & \multirow[t]{2}{*}{ Wald } & \multirow[t]{2}{*}{$d f$} & \multirow[t]{2}{*}{ Sig. } & \multirow[t]{2}{*}{$\mathrm{HR}$} & \multicolumn{2}{|c|}{$95.0 \% \mathrm{Cl}$ for $\mathrm{HR}$} \\
\hline & & & & & & & Lower & Upper \\
\hline Exposure 1 & 1.714 & .453 & 14.308 & 1 & .000 & 5.550 & 2.284 & 13.488 \\
\hline Combined Climates (1) & 1.249 & .481 & 6.742 & 1 & .009 & 3.488 & 1.358 & 8.955 \\
\hline Combined Climates (2) & 1.099 & .476 & 5.334 & 1 & .021 & 3.001 & 1.181 & 7.626 \\
\hline Combined Climates (3) & .501 & .610 & .676 & 1 & .411 & 1.651 & .500 & 5.453 \\
\hline Aging 1 & .619 & .293 & 4.476 & 1 & .034 & 1.857 & 1.047 & 3.295 \\
\hline
\end{tabular}

SE standard error, $H R$ hazard ratio

Exposure1 = exposure to pollution

Combined climates $(1)=$ combined local dry season and global Lanina

Combined climates $(2)=$ combined local dry season and global Elnino

Combined climates $(3)=$ combined local rainy season and global Lanina

seasons and climates, global climate variability and the interaction between global and local climates were tested as oxidant conditions for emerging $\mathrm{HM}$ at KUC, Kinshasa Province, DRC. Therefore, univariate analysis and a multivariate Cox's regression model were used to understand the pathophysiology and the environmental epidemiology (ecology) of HM incidence in a prospective cohort for anaemic patients managed at KUC. The present findings defined potential predictors and biomarkers as well as risk factors of incident HM.

\section{Descriptive characteristics}

The present study confirmed an emerging burden of HM incidence among anaemic patients with an estimated incidence rate of $60 \%$. This magnitude was almost eight-fold higher than the HM incidence of $8.7 \%$ reported for subSaharan Africa in $2008[1,20]$. The present Congolese epidemic of HM (an incidence rate of $60 \%$ in 2016) was already close to the $\mathrm{HM}$ incidence rate projected to be $75 \%$ by 2030 for all of sub-Saharan Africa [1, 7]. Among the patients with incident HM $(n=63)$, this study confirmed AML and MM as the most prevalent malignancies, which is similar to previous reports from Kinshasa, DRC and other parts of Africa $[1,6,11]$.

\section{Potential risk factors for HM}

In this study, aging, sepsis, bacteraemia, HIV/AIDS, hematologic markers, exposure to pollution, local climate, global climate variability and combined global and local climate were identified as potential univariate predictors of HM incidence. As reported in the literature [21, 22] and by the present study, sex (sex ratio $=1)$ was not significantly associated with AML, with CML or with ALL. However, male sex or female sex were significantly associated with other HM subtypes, as follows: male predominance in the MM and MDS subtypes and female predominance in the CLL subtype.

\section{HIV/aids}

As has been reported in both developed and poor countries [1, 23-32], a univariate significant association exists between HM and HIV for patients both taking and not taking antiretroviral therapy. In sub-Saharan Africa, including DR Congo, HIV infection (well established as an oxidative stress condition [15]), the Epstein-Bar virus (EBV), the Kaposi sarcoma-associated herpes virus (KSHV), and malaria (a condition of endothelial dysfunction, a risk factor of HM oxidative stress [32]) are all identified as significant ecological risk factors of HM [1, 33-37].

\section{Independent predictors of HM incidence}

In this study using multivariate Cox's regression analysis, only exposure to pollution, combined local dry season + global La Nina climate variability, combined local dry season + global El Nino climate variability, and age $\geq 50$ years were identified as the most significant and independent predictors of HM-incidence among anaemic black Central Africans. Climate change leads to over-exposure to ultraviolet rays and lower levels of vitamin D, resulting in decreased levels of immunity. In addition, chronic exposure to benzene products, lead and mercury in the environment increases the risk of HM. Climate change, environmental pollution, aging and anaemic hypoxia are associated with an imbalance in the anti-oxidant/oxidant state (oxidative stress), which increases the risk of HM incidence [13, 21, 38-46].

Aging in particular is associated with the pathogenesis of clonal myeloid diseases such as chronic myeloid leukaemia [47]. In Kinshasa, the early warning system impacts local seasons, climate variability (La Nina and El Nino) and ischemic stroke morbidity and mortality [16].

\section{Clinical implications and perspectives for public health}

The findings of this study will contribute to the body of scientific knowledge on HM. This epidemiological data will also contribute to capacity enhancement, treatment, clinical services, advocacy and prevention of $\mathrm{HM}$ at 
KUC. It is timely information and requires a response from the Congolese government and Kinshasa University regarding improvements in early diagnosis, chemotherapy, radiotherapy, hematopoietic stem cell transplantation, supportive care and rehabilitation for HM patients. These remain challenges in DR Congo and sub-Saharan countries [1].

\section{Strengths and limitations}

The novelty of this study was an opportunity to use a rigorous, probabilistic and prospective approach to identifying predictors of HM in Kinshasa, DRC. However, this study was limited because of a lack of cytogenetic methods. The present findings cannot be generalized to the general population of DR Congo.

\section{Conclusion}

These findings highlight the importance of HIV/AIDS, aging, environmental pollutions, the dry season, El Nino and La Nina as related to global warming as determinants of incident hematologic malignancies among black anaemic patients in Kinshasa, DR Congo. While significant findings have been documented on the HV/AIDS epidemic, concerted efforts of individuals, government and donor agencies are needed to address environmental pollution in Kinshasa and DRC in view of the current findings. Global leaders should be encouraged to double their efforts on global warming for the overall benefit of mankind and specifically to reduce the scourge of incident HM and other malignancies. Cancer registries in DRC and other African countries will provide more robust database for future researches on haematological malignancies in the light of the findings of this study.

\section{Abbreviations \\ ALL: Acute lymphoid leukaemia; AML: Acute myeloid leukaemia; CLL: Chronic lymphoid leukaemia; CML: Chronic myeloid leukaemia; DRC: Democratic Republic of Congo; EDTA: Ethylenediaminetetraacetic acid; FAB: French- American-British Classification System; HM: Hematological malignancies; KUC: Kinshasa University Clinics; MDS: Myelodysplastic syndrome; MGG: May Grunwald Giemsa; MM: Multiple myeloma; NCD: Non-communicable diseases; ONI: Oceanic Nino Index; ROC: Receiver operating characteristic curve; SD: Standard deviation; T2DM: Type 2 diabetes mellitus}

\section{Acknowledgements}

The authors are grateful to the staff of Kinshasa University Clinics in DR Congo for their support towards the successful implementation of the study. The authors also thank Jane Mqamelo for English editing.

\section{Funding}

No funding was received for the study.

\section{Availability of data and materials}

Data will be made available on reasonable request from the corresponding authors.

\section{Authors' contributions}

All authors gave intellectual inputs to the study protocol and the draft of the manuscript. Data collection was conducted under the supervision of MSNN ${ }^{1}$ $\mathrm{JBN}^{4}, \mathrm{ALK}^{5}, \mathrm{PRBK}^{6}$ and $A N N^{7}$ while data analysis and interpretation were conducted by BLM ${ }^{2}$ and $\mathrm{OVA}^{3}$. All authors approved the final draft of the manuscript for submission.

\section{Ethics approval and consent to participate}

The Ethics Committee, School of Public Health (University of Kinshasa) granted the approval for this study. Administrative permission was also obtained from the Head of the Department of Clinical Biology. Each participant signed a written informed consent after receiving detailed information on the purpose of the study. Participants were managed in accordance with the Helsinki Declaration.

Consent for publication

Not applicable.

\section{Competing interests}

The authors declare that they have no competing interests.

\section{Publisher's Note}

Springer Nature remains neutral with regard to jurisdictional claims in published maps and institutional affiliations.

\section{Author details}

${ }^{1}$ Département de Biologie Médicale, Service de Biologie Clinique, CUK, Faculté de Médecine, Kinshasa, Democratic Republic of Congo. ${ }^{2}$ Centre Hospitalier OVD, Kinshasa, Democratic Republic of Congo. ${ }^{3}$ Hôpital SaintJoseph, Kinshasa, Democratic Republic of Congo. ${ }^{4}$ Faculty of Health Sciences, Walter Sisulu University, Private Bag X1, 5117 Mthatha, South Africa. ${ }^{5}$ Cecilia Makiwane Hospital/Walter Sisulu University, Faculty of Health Sciences, East London, South Africa.

Received: 19 December 2016 Accepted: 14 August 2017

Published online: 23 August 2017

\section{References}

1. Gopal S, Wood WA, Lee SJ, et al. Meeting the challenge of hematologic malignancies in sub-Saharan Africa. BLOOD; 31 May 2012 Volume 119, No 22.

2. Lichtman MA. Battling hematological malignancies: the 200 years' war. Oncologist. 2008;13(2):126-38.

3. Torre LA, Bray F, Siegel RL, et al. Global cancer Statistics, 2013. A cancer journal for clinicians. Volume 65, Issue 2 March/April 2015; p. 87-108.

4. INSERM. Collective expert reports. A methodological approach for studying the link between cancer and the environment: Cancer; 2005.

5. Hossain MS, labal MS, Khan MA, et al. Diagnosed hematological malignancies in Bangladesh-a retrospective analysis of over 5000 cases from 10 specialized hospitals. BMC Cancer. 2014;14(1):438.

6. Errahhali ME, Errahhali ME, Boulouiz R, et al. Distribution and features of hematological malignancies in Eastern Morocco: a retrospective multicenter study over 5 years. BMC cancer. 2016;16(1):159.

7. OMS, La fréquence des cancers pourrait augmenter de $50 \%$ dans le monde, avec 15 millions de nouveaux cas en 2020. Centre des médias; 2003.

8. Mufuta NJP, Mbayo K, Kayembe NZ, et al. Cytologie des hémopathies malignes dans deux formations médicales de Kinshasa /DRCongo Ann. Afr. Med Vol. 6 No 4; 2013.

9. Mashinda KD, Kayembe KP, Mapatano MA. Prévalence du cancer en République Démocratique du Congo: données anatomopathologiques recueillies aux Cliniques Universitaires de Kinshasa et à l'Hôpital Général de Référence de Kinshasa Ann. Afr. Med. Vol 6 No 4; 2012.

10. Diallo DA, Sissoko LS, Sissoko Y, 4 et al. Epidémiologie actuelle des hémopathies malignes dans les services d'hématologie oncologie médicale et de médecine interne de l'hôpital du Point G, Bamako, Mali. Mali Médical; 2005. T XX No 4.

11. Diagnekpo T, Toutoupo $Y$, Abissey A, et al. Panorama des hémopathies malignes diagnostiquées au Laboratoire Central du CHU de Treichville Bilan de 10 années d'activités Médecine d'Afrique Noire. 1992; 39(4).

12. Mounkaila B, Touré $\mid A$, Gragnic Gl. Mounkaila Hémopathies malignes à Niamey À propos de 90 observations sur 6 ans Médecine d'Afrique Noire. 1996; 43 (8/9)

13. Fleming AF. Leukemias in Africa. Leukemia. 1993; Vol 7, suppl 2.S138-41.

14. Karstaedt AS, Plantanowitz L, Omar T, et al. The utility of bone-marrow examination in HIV-infected adults in South Africa QJ Med 2001; p. 94: 101-105. 
15. Longo-Mbenza B, Phanzu-Mbete LB, M'Buyamba-Kabangu JR, et al. Hematocrit and stroke in black Africans under tropical climate and meteorological influence. Ann Med Interne (Paris). 1999; Apr; 150(3):171-7.

16. Kintoki Mbala F, Longo-Mbenza B, Mbungu Fuele S, et al. Impact of seasons, years el Nino/la Nina and rainfalls on stroke-related morbidity and mortality in Kinshasa. Journal des maladies vasculaires Février. 2016:41(1):4-11.

17. Chandan, J S. Statistics for Business and Economics. Delhi: Vikas Publishing House, 1998; p. 196-215.

18. Zhou, G, Minakana, N, Githeko, AK et al. 2005. Climate variability and malaria epidemics in the highlands of East Africa. Trends in parasitology Vol. (21), p. 54-56/ intergovernmental panel on climate change (IPCC), 2007. Annual report.

19. Mantilla G, Oliveros H, Barnston AG. The role of ENSO in understanding changes in Colombia's annual malaria burden by region, 1960-2006. Malaria journal. 2009:8(1):6. Doi:10.1186/1475-2875-8-6.

20. Schonfeld SJ, Erdmann F, Wiggill T, et al. Hematologic malignancies in South Africa-2006: analysis of data reported to the National Cancer Registry. Cancer Med. 2016; April 5(4): 728-38.

21. Omoti $\mathrm{CE}^{-1}$, Nwannadi $\mathrm{Al}^{1}$, Obieche $\mathrm{JC}^{1}$, Noma Olu-Eddo $\mathrm{A}^{1}$. The Epidemiological features of lymphoid malignancies in Benin City, Nigeria: A 15 years' study. The Pan African Medical Journal. 2012; 11:10.

22. Nwannadi IA, Alao OO, Bazuaye GN, Halim NKD, Omoti CE. The Epidemiology of Haematological Malignancies at the University Of Benin Teaching Hospital: A Ten-Year Retrospective Study. The Internet Journal of Epidemiology. 2010; Volume 9 No 2.

23. Patel P, Hanson DL, Sullivan PS, et al. Incidence of types of cancer among HIV-infected persons compared with the general population in the United States, 1992-2003. Ann Intern Med. 2008;148(10):728-36.

24. Engels EA, Pfeiffer RM, Goedert JJ, et al. Trends in cancer risk among people with AIDS in the United States 1980-2002. AIDS. 2006:20(12):1645-54.

25. Grulich $A E$, van Leeuwen MT. Falster $M O$, et al incidence of cancers in people with HIV/AIDS compared with immunosuppressed transplant recipients: a meta-analysis. Lancet. 2007;370(9581):59-67.

26. Mbulaiteye SM, Katabira ET, Wabinga $\mathrm{H}$, et al. Spectrum of cancers among HIV-infected persons in Africa: the Uganda AIDS-cancer registry match study. Int J Cancer. 2006;118(4):985-90.

27. Sasco AJ, Jaquet A, Boidin E, et al. The challenge of AIDS-related malignancies in sub-Saharan Africa. PLoS One. 2010;5(1):e8621.

28. Bohlius J, Schmidlin K, Boué F, et al. HIV-1-related Hodgkin lymphoma in the era of combination antiretroviral therapy: incidence and evolution of CD4 ${ }^{+}$T-cell lymphocytes. Blood. 2011;117(23):6100-8.

29. Simard EP, Engels EA. Cancer as a cause of death among people with AIDS in the United States. Clin Infect Dis. 2010;51(8):957-62.

30. Bonnet F, Burty C, Lewden C, et al. Changes in cancer mortality among HIVinfected patients: the Mortalité 2005 survey. Clin Infect Dis. 2009:48(5):633-9.

31. Antiretroviral Therapy Cohort Collaboration. Causes of death in HIV-1infected patients treated with antiretroviral therapy, 1996-2006: collaborative analysis of 13 HIV cohort studies. Clin Infect Dis. 2010;50(10):1387-96.

32. Fiaschi T, Chiarugi P. Oxidative stress, tumor microenvironment and metabolic reprogramming: a diabolic liaison. International Journal of cell Biology volume. 2012; doi:https://doi.org/10.1155/2012/762825

33. Joint United Nations Program on HIV/AIDS (UNAIDS). Global HIV/AIDS response: progress report 2011

34. Mwakigonja AR, Kaaya EE, Heiden T, et al. Tanzanian malignant lymphomas: WHO classification, presentation, ploidy, proliferation and HIV/EBV association. BMC Cancer. 2010;10(1):344.

35. Naresh KN, Raphael M, Ayers L, et al. Lymphomas in sub-Saharan Africa: what can we learn and how can we help in improving diagnosis, managing patients and fostering translational research? Br J Haematol. 2011;154(6): 696-703.

36. Cohen Jl. Epstein-Barr virus infection. N Engl J Med. 2000;343(7):481-92.

37. Wiggill TM, Mantina $H$, Willem $P$, et al. Changing pattern of lymphoma subgroups at a tertiary academic complex in a high prevalence HIV setting: a south African perspective. J Acquir Immune Defic Syndr. 2011:56(5):460-6.

38. Dongre NN, Suryakar AN, Patil AJ, Rathi DB. Occupational lead exposure in automobile workers in North Karnataka (India): effect on liver and kidney functions. Al Ame en J Med Sci. 2010;3(4):284-92.

39. Natelson EA. Benzene-induced acute myeloid leukemia: a clinician's perspective. Am J Hematol. 2007:82(9):826-30.

40. Jomova K Valko M. Advances in metal-induced oxidative stress and human disease Toxicology 2011 May 10: 283 (2-3): 65-87.
41. Ziello JE, Jovin IS, Huang Y. Hypoxia-Inducible Factor (HIF)-1 Regulatory pathway and its potential for therapeutic intervention in malignancy and ischemia. Yale J Biol Med. 2007; Jun;80(2):51-60.

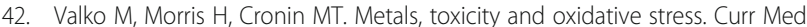
Chem. 2005;12(10):1161-208.

43. Reuter S, Gupta SC, Chaturvedi MM, et al. Oxidative stress, inflammation, and cancer: how are they linked? Free Radic Biol Med. 2010;49(11):1603-16.

44. Buijsse B, Feskens EJ, Moschandreas J, et al. Oxidative stress, and iron and antioxidant status in elderly men: differences between the South Mediterranean (Crete) and northern Europe (Zutphen.). Eur. J. Cardiovasc. Prev. Rehab. 2007:14:495-500.

45. Rericha V, Kulich M, Rericha R, et al. Sandler incidence of leukemia, lymphoma, and multiple myeloma in Czech uranium miners: a case-cohort study. Environ Health Perspect. 2006;114:818-22.

46. Muz B, de la Puente P, Azab F, et al. The Role of Hypoxia and Exploitation of the Hypoxic Environment in Hematologic Malignancies Mol Cancer Res, 2012; 12(10)1347-1354.

47. Lichtman MA, Rowe JM. The relationship of patient age to the pathobiology of the clonal myeloid diseases. Semin Oncol. 2004;31:185-97.

\section{Submit your next manuscript to BioMed Central and we will help you at every step:}

- We accept pre-submission inquiries

- Our selector tool helps you to find the most relevant journal

- We provide round the clock customer support

- Convenient online submission

- Thorough peer review

- Inclusion in PubMed and all major indexing services

- Maximum visibility for your research

Submit your manuscript at www.biomedcentral.com/submit
) Biomed Central 